\title{
Theoretical Considerations to Improve a Good Questionnaire on Tolerance
}

\author{
Ylli H. Doci
}

\begin{abstract}
The need for tolerance or buttressing existing tolerance is very important for the cohesion of our pluralistic society hence the measuring of tolerance is very helpful in considering intelligent ways to foster tolerance in a specific context. Theoretical considerations about the meaning of tolerance and the factors involved in obtaining tolerance are crucial in building a good measuring tool. A sustained good theoretical effort is appraised here in evaluating some aspects of one such good tool, a questionnaire developed to measure the tolerance of last year students of education. But we also can see how a certain understanding of tolerance with regard to relativism can improve this questionnaire to not filter out some tolerant people with exclusive views of truth.
\end{abstract}

Keywords: Theoretical, considerations, improve, good questionnaire, tolerance

\section{Introduction}

\begin{abstract}
Albania and interreligious tolerance: The occasion for this inquiry
Albania, where five differing religious traditions of Muslims (Sunni and Bektashi) and Christians (Orthodox, Catholic and Protestant) have lived side by side peacefully, ${ }^{1}$ is a refreshing case in the gloomy situation of many parts of the world suffering from inter-religious strife and violence. ${ }^{2}$ On the other hand, Albania is not immune from the evils of extremism experienced in other parts of the world not least because Albania has been opened wide to the world with its various influences for the last 25 years and there are reports of Albanian Muslims fighting in the ISIS ranks. ${ }^{3}$ In order to protect the peace and promote tolerance in Albania I found it important to understand the factors contributing toward this desired outcome and measure the status of such factors today in order to more effectively focus on the areas needing improvement. In considering one questionnaire to measure tolerance in Albania it was very helpful to consider the process described for developing of this tool. ${ }^{4}$
\end{abstract}

\section{Theoretical considerations in measuring tolerance:}

Some key factors related to having a tolerant environment between individuals in a society include awareness of specific beliefs at variance with one's own and exercise of freedom with respect in interaction. Recognizing the need to define well the important factors making for tolerance in order to look for them in a certain social environment we need to start with a good understanding of tolerance itself and develop a working definition, which would control the work to clarify the specific components required for acquiring tolerance.

The authors of the questionnaire I evaluated for use in Albania were transparent about their goals and theoretical underpinnings of their understanding of tolerance and it was evident that a lot of good thinking had gone into preparing this questionnaire. They start with saying: "Tolerance, therefore, is intimately connected to the affirmation of the most basic dimension of freedom - the freedom of belief and conscience. " 5 In the second section of their article we find outlined the

\footnotetext{
${ }^{1}$ Giovanni Cimbalo, Pluralizmi i besimit dhe komunitetet fetare ne Shqiperi, Studime te se drejtes se krahasuar. E drejta kishtare dhe te drejtat njerezore. (Tirana, Albania: Naimi, 2013).

2 "The Discrimination and Persecution of Christians: The 50 Worst Countries. Draft for Comment by Consultation Delegates." (International Institute for Religious Freedom commissioned by Global Christian Forum. October 15, 2015).

${ }^{3}$ Fatjona Mejdini, "Drop in Albanian ISIS Fighters Reflects 'Low Demand,"' Interview, BalkanInsight, (August 11, 2016), http://www.balkaninsight.com/en/article/the-decline-of-albanians-fighting-with-isis-related-mostly-with-low-demand-08-11-2016.

${ }^{4}$ Nico A Broer et al., "Measuring Religious Tolerance among Final Year Education Students. the Birth of a Questionnaire.," International Journal for Religious Freedom (IJRF) 7, no. 1/2 (2014).

5 lbid., 77.
} 
understanding of tolerance that guides the authors in preparing the questionnaire. Starting with what tolerance is not, gleaning from several thinkers such as Furedi, ${ }^{1}$ Boersma, ${ }^{2}$ Saulius, ${ }^{3}$ they believe that: "tolerance is not a disinclination to judge or to have strong views, " "not a superficial signifier of acceptance and affirmation of anyone and everyone, " "not a form of detached indifference or... automatic acceptance, " "not 'a necessary but passive act of putting up with someone else's view'... deemed wrong or inferior, " "does not mean that one has to respect those lifestyles, or even regard them as morally equal to one's own practice. "4 Positively then, the concept of freedom is put forth including "the principle of noninterference towards the way people develop and hold beliefs and opinions" 5 affirming individual autonomy basically affirming what I believe to be an important feature of robust tolerance, namely freedom of conversion. I especially appreciate emphasizing of the necessary "context of difference (s)" saying: "Tolerance comes into play when different individuals and groups have conflicting beliefs and/or act in unacceptable ways (morally, politically or in a religious sense). "6 This aspect will come into play in our analysis below when we discuss relativism which here, assuming differences are perceived as real and important, it appears to be excluded from serving as the context for tolerance. Respect is helpfully qualified in different ways including "regard[ing] one another as moral equals... [holding that] tolerance always also calls for judgment, evaluation and discrimination. "I Important as well is the authors' emphasis of "a person's values or ethical system"8 which I would broaden to include or at least imply awareness of specific beliefs important in one's own worldview as well as in the worldview of the others toward whom tolerance is extended. They end their survey of seven aspects of tolerance with defining it as: "... that respectful, meaningful and empathetic attitude of people or groups which in a context of differences, acknowledges and defends the right of individuals and groups of people to cherish freely certain beliefs and values while accepting that others possess the freedom and right to evaluate and judge those same beliefs and values in terms of their own value systems. "

I could not agree more with this conclusion that exploring concepts of freedom, of convictions, of respect for people, of the importance of beliefs and practices and of evaluation of ideas with which one disagrees or finds unacceptable, providing for a space where everyone can hold his views freely and openly, including also the need for engagement of the other in a free, meaningful and understanding way, are all valuable discussions to inform our pursuit of measuring tolerance. I also agree that tolerance can be seen as a quality of attitudes expressed in interactions between people of different persuasions, allowing for commonalities to enable living together in the same social space so that different parties progressively grow toward ever increasing cooperation for the good of all in that society. They say it well: "The future of society and the maintenance of a peaceful modus vivendi in a diverse society depend to a significant extent on the tolerance of individuals and groups. "10

Attitudes as internal states of consciousness or dispositions can be described and put in a specific way to be indicated clearly in a questionnaire for outsiders to understand. Interactions qualifying as tolerant, evidencing respect, freedom or understanding and empathy, can also be defined and described in a questionnaire as evidentially recognizable in somebody's life. Differing persuasions are assumed to be inherent in identifying with differing religions or world and life views, which can simply be identified as such in a questionnaire. What I found very helpful in the article by Nico Broer and his coauthors introducing the questionnaire was the presenting of the work done to translate these categories and more ${ }^{11}$ into items of a questionnaire explaining their correspondence to such factors as "value of own religion, " "respect, " as illustrated in the table below.

\footnotetext{
1 Frank Furedi, "'On Tolerance,"' Policy 28, no. 2 (Winter 2012): 30-37.

2 P. Boersma, Personal Communication (The Netherlands: Besturendraad, 2012).

3 T. Saulius, "What Is 'Tolerance' and 'Tolerance Education'? Philosophical Perspectives.," Ugdymas. Kuno Kultura. Sportas. Socialiniai Mokslai. 89, no. 2 (2013): 49-56.

${ }^{4}$ Broer et al., "Measuring Religious Tolerance among Final Year Education Students. the Birth of a Questionnaire.," 83.

5 lbid., 84.

6 lbid.

7 lbid., 85.

8 lbid.

9 lbid., 86.

$10 \mathrm{lbid}$.

11 Valuable discussions on the inculcation of values and the role of education figure prominently in the framework of the questionnaire through p.87-88, but I am reducing the discussion here to a more general view of tolerance.
} 
In the context of this overwhelming agreement with the work reviewed here I want to draw attention to two aspects I wish were better reflected in the questionnaire.

\section{Conversion as one explicit aspect missing in the questionnaire:}

Basic categories of tolerance, as we have already said in different ways, include awareness of one's own specific beliefs and bearing with or endurance of another whose beliefs are at variance or contradictory to one's own. But I also believe it should include the freedom of conversion to either of the view points as a right of the individuals in the common social space they live in. My working definition for tolerance therefore is: "Tolerance exists between two people or groups when intentionally or knowingly one respects the other who holds and practices opposing views to the point of having both parties endure, without unjust hindrance, even the free conversion of anyone to the other's point of view. " I believe similarly to the authors of this questionnaire, that for tolerance to appear there needs to be some level of personal conviction, interpersonal interaction, and respected personal freedoms. ${ }^{2}$ But I would like to emphasize that a robust tolerance includes refraining from hindering unjustly the free conversion of anyone to the other's idea implying positively also freedom for conversion. ${ }^{3}$ This is in agreement with the often quoted Furedi, who writes: "... tolerance can be measured in relation to the extent to which people's belief and behaviour is not subject to institutional and political interference and restraint. "4 But, this aspect of tolerance, namely the freedom for conversion, doesn't seem to feature clearly in the questionnaire and I wonder if it would have helped to include some item in this regard. Not making explicit some aspect is not necessarily a problem while positively filtering out as intolerant a tolerant person's answer may be a problem and this is the second more serious issue to discuss.

\section{Tolerance and Relativism in the questionnaire:}

I will take issue here with only one of the questionnaire items, which seems to contradict one aspect of my view of tolerance, namely the incompatibility of relativism and tolerance. Analyzing the relationship of relativism and tolerance I have come to the conclusion that we need to detect and expose the relativistic stance because it actually removes the conditions for tolerance to exist.

Jay Newman writes: "Tolerance, after all, does not demand that one believe that every other person's metaphysical views are as true or as reasonable or as profound as his own. Indeed ... tolerance is possible only because we are capable of

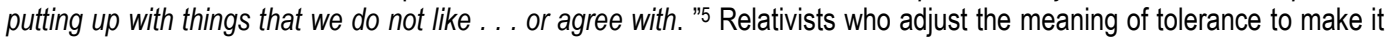
more of a propositional attitude, which considers respecting another's religious beliefs as being of equal truthfulness to the truth claims of one's own convictions, is nonsensical. This is so because a person could end up holding as equally true both propositions: his own, and at the same time and in the same respect that of the another, even if they are obviously contradictory. It should be clear that a tolerant person, meaning a respectful person toward others who hold contradictory views to one's own, does not need to hold "that all religions lead to one and the same truth."

Considering this understanding then, item 33 in the questionnaire indicating as respectful "I believe that all religions of life and world views in the end lead to one and the same truth"6 could filter as intolerant by lacking in respectfulness some tolerant but nonrelativistic people. This statement of item 33 seems to assume that following any of the religions leads to the same ultimate truth and that believing this reflects respect for the religious other. I recognize that this item could be simply one way to identify those who would not fit the intolerant category even for the wrong philosophical reasons, namely

\footnotetext{
${ }^{1}$ I have developed these ideas in a paper pending publication.

2 Nico A Broer et al., "Measuring Religious Tolerance among Final Year Education Students. the Birth of a Questionnaire.,"83. Referring to Potgieter et al (2014:3) writes that tolerance 'involves decision-making based on a certain value system, ethical behavior, reasonable argument, difference, as well as a spectrum of behavior.'

3 Thomas Schirrmacher, Human Rights. Promise and Reality, ed. Thomas K. Johnson, trans. Richard McClary, vol. 15 (Bonn: Verlag Für Kultur und Wissenschaft. Culture and Science publ., 2014), 72-75. Here is a good discussion of the meaning of religious freedom indicating the legitimate limitations in light of other human rights and pointing out illegitimate ones while emphasizing "a famous ruling by the European Court of Human Rights (ECHR) dated May 25, 1993... [saying] 'The freedom of thought, conscience and religion is one of the foundations of a democratic society'".

${ }^{4}$ Furedi, "'On Tolerance," 31.

5 Jay Newman, Foundations of Religious Tolerance (Toronto: University of Toronto Press, 1982), 61.

${ }^{6}$ See table with selected items and notice item 33 in the category measuring respect. In the published article presenting the questionnaire it was item number 35.
} 
relativistic people who nevertheless are tolerant, but I would disagree that it necessarily reflects respect because it may also reflect patronizing some people with irrelevant ideas.

I would have modified this question into something like: "Even if my neighbor's religion would lead to a different ultimate truth than mine, I would respect him and his right to believe differently. "I believe it is more helpful to correct question 33 to fit better with the view of tolerance as defined by rejecting relativism, thus removing the small but still incorrect measuring with item 33 of the attitude of some tolerant people as intolerant because of their rejection of relativism. It is not a major measuring problem for the questionnaire as a whole but being one of seven items measuring respect, it is not irrelevant.

In spite of my one serious reservation explained above, for all practical purposes, the questionnaire is very well suited to measure tolerance and I recommend it to everyone. I conducted this questionnaire with last year students of education at the University of Shkodra, Albania, in June 2016.

\section{References:}

[1] Boersma, P. Personal Communication. The Netherlands: Besturendraad, 2012.

[2] Broer, Nico A, Bram de Muynck, Ferdinand J Potgieter, Charste $C$ Wolhuter, and Johannes $L$ van der Walt. "Measuring Religious Tolerance among Final Year Education Students. the Birth of a Questionnaire." International Journal for Religious Freedom (IJRF) 7, no. 1/2 (2014).

[3] Cimbalo, Giovanni. Pluralizmi i besimit dhe komunitetet fetare ne Shqiperi. Studime te se drejtes se krahasuar. E drejta kishtare dhe te drejtat njerezore. Tirana, Albania: Naimi, 2013.

[4] Furedi, Frank. "'On Tolerance. "' Policy 28, no. 2 (Winter 2012): 30-37.

[5] Mejdini, Fatjona. "Drop in Albanian ISIS Fighters Reflects 'Low Demand. '” Interview. BalkanInsight, August 11, 2016. http://www. balkaninsight. com/en/article/the-decline-of-albanians-fighting-with-isis-related-mostly-withlow-demand-08-11-2016.

[6] Newman, Jay. Foundations of Religious Tolerance. Toronto: University of Toronto Press, 1982.

[7] Saulius, T. 'What Is 'Tolerance' and 'Tolerance Education'? Philosophical Perspectives. " Ugdymas. Kuno Kultura. Sportas. Socialiniai Mokslai. 89, no. 2 (2013): 49-56.

[8] Schirrmacher, Thomas. Human Rights. Promise and Reality. Edited by Thomas K. Johnson. Translated by Richard McClary. Vol. 15. Bonn: Verlag Für Kultur und Wissenschaft. Culture and Science publ., 2014.

[9] "The Discrimination and Persecution of Christians:The 50 Worst Countries. Draft for Comment by Consultation Delegates. " International Institute for Religious Freedom commissioned by Global Christian Forum., October 15, 2015.

[10]Appendix: Selected questionnaire items (out of 50) for each measuring factor relevant to tolerance

Respect

24. I think that I am contributing to the wellbeing of my fellow human beings when I respect their ideas and beliefs.

33. I believe that all religions of life and world views in the end lead to one and the same truth.

41. I am convinced that I am able to participate in society taking into account the values and norms which are important to me.

43. I am convinced that people despite the differences between them should seek a peaceful co-existence.

44. I am convinced that people should pay so much respect to one another that peaceful co-existence between them can be possible.

45. I am convinced that people should seek ways to overcome the differences that exist among people in society. 
46. I am of the opinion that people should respect the differences that exist among different people in society.

Empathy

07. I am on friendly foot with people who adhere to another religion or life and world view.

08. I do not feel threatened by the world around me.

38. I respect the religious beliefs of people with convictions quite different from mine.

48. I respect and do not condemn people whose beliefs are different from mine.

50. I feel free to respectfully socialize with people who hold beliefs quite different from mine.

Value of own religion

15. The values and norms, which are important to me, all stem from my religion or life and world view.

16. The values and norms, which are important to me, cause me to be quite different from other people.

31. I believe that my own religion or life and world view is the only correct one.

32. I think that people can arrive at the truth only via my religion or life and world view.

36. I am convinced that people should adhere to principles contained in a holy scripture.

Sens of freedom

09. I can comfortably get along with someone who adheres to norms and values different from my own.

10. All people should be able to get along with one another, regardless of which norms and values are important to them.

11. There are norms and values which should be important to all people, regardless of their own religion/life and world views.

13. In my encounters with people who adhere to another religion or life and worldview I always remain faithful to my own norms and values.

20. I am able to explain to others those values and norms which are important to me.

Sensibility to differences

06. I do not care what people who adhere to another religion of world view think, find or do.

22. I do not care what other people think, find and do based on their own religion or life and worldview.

25. I find it easy to accept other people's behaviour which I myself do not find acceptable.

40. I do not care whether my country is governed by Christians, Muslims, Hindus, Buddhists or New Age followers.

Origins of own values

18. The values and norms which are now important to me were imbued to me by my parents.

19. The values and norms which are now important to me were imbued to me by the school (s) that I attended. 